\title{
Development of the Body Care E-Modul Learning Based on Discovery Learning in Department of Cosmetology Education on Students at Universitas Negeri Medan
}

\author{
Wuri Dwiyati ${ }^{1}$, Harun Sitompul ${ }^{2}$, R. Mursid ${ }^{3}$ \\ \{dwii.wuridwiyatispd@gmail.com ${ }^{1}$ \} \\ Education Technology Postgraduate Program, Universitas Negeri Medan ${ }^{1}$, \\ Fakultas Teknik Universitas Negeri Medan, Indonesia ${ }^{2,3}$
}

\begin{abstract}
The study is intended to: (1) determine the feasibility of e- module learning care agency-based discovery learning, and (2) determine the effectiveness of the e-module learning care agency-based discovery learning. Type of research this is the research development using the product Borg and Gall were combined with the model of development of learning Dick and Carey. This model includes six stages namely: literature study, planning and design development, product development, expert validation, trials, revisions, and final products. Subject test try consists of a two- person expert material twoperson expert design of learning, two expert video media learning, three the students to test individual, Nine students for the test group of small, and four thirty the students to test the field. The result of the filing of hypotheses prove that: (1) the media e-modules of learning worthy of use in learning care agency on the program of study education that a dressing university land terrain, (2) there is a difference that is significant between the results of learning of students who be taught to use the e-module learning care agency with the result of learning of students who be taught to use the media to learn the book text. This is indicated by the results of data processing $t$ arithmetic $=3.285$ at a significance level $\alpha=$ 0.05 with $\mathrm{dk} 40$ obtained $\mathrm{t}$ table $=1.67$, so $\mathrm{t}$ arithmetic $>\mathrm{t}$ table, the effectiveness of using e- module body care learning $=80.46 \%$. Results of study groups of students who taught without the use of e-module learning care agency by $71.72 \%$. From the data have proved that the use of e-module learning care agencies more effective in improving the competence and knowledge of students on study treatment weight of at without using the medium of emodules of learning care.
\end{abstract}

Keywords: Discovery Learning, Development of E-Module, Learning Care Agency

\section{Introduction}

Information and Communication Technology (ICT) is currently highly developed in society. Generally, Information Technology is a technology that is used to manage data, including in it: processing, obtaining, compiling, storing, manipulating data in a variety of ways and procedures to produce quality information and high-value use. The development of ICT continues to increase along with the increasing human needs, especially in the field of Education [1]. At present the trend of the use of e-electronic, which means a lot of emerging, such as eeducation, e-learning, and so on, including the use of e-modules. At present information 
technology seems to have become a teacher, book and learning system that is conventional. By because it is, with increasingly growing progress in the field of science knowledge and technology Institutions especially college high that competence in the field of vocational already preparing the source power of man that is the students who are competent in the field of expertise of each one of them in the field of expertise order beauty or cosmetology.

Universitas Negeri Medan is one of the Institutions of Education State which has a program expertise competence vocational in the field of governance of beauty. Program Study of Educational Makeup Department of Education Welfare and Family Faculty of Engineering is a program of study that opened since the teachings of 2007/2008 was one of the efforts to meet the needs in the community will be the teachers professional and skilled in the fields of cosmetology in the future will come. Improved quality of teaching in universities high, especially in institutes of Education personnel education is and must continue to be improved. Based on the results of interviews with faculty supporting lecturer of college nursing agency implemented on the date of 17 January 2019 can be concluded that during these lectures carried out only with the methods of lecture and demonstration. Practices are simulated first advance by the lecturers can spend time almost 2 credits and subsequent student practice it together. While the result of learning of students associated with the eyes of college nursing agency, the data obtained from the results of learning of students in the eyes of college nursing agency in the teachings of $2016 / 2017$ is said to be good. This can be seen from there are $22.85 \%$ who get very good grades and $77.15 \%$ who get good grades. Although the result of learning of students in the eyes of college nursing agency pertained to say good, but still need to be improved so that the results of study a student may be retained or more improved again so that the purpose of the process of learning can be achieved in accordance with the expected.

The role of lecturers as educators is needed to motivate student enthusiasm for learning. Lecturer is seen as a person who knows a lot of things about the conditions of learning and also the problems of learning that faced by students. Lecturers are creative are always innovating and looking for ways how to make the process of learning to teach achieve the result of learning in accordance with the objectives that are planned. Based on the results of observations are made on the date of 25 January 2019 with the lecturer eyes of college nursing agency can be concluded that the reactions of students during the process of learning care agency is a student looks very enthusiastic both from the terms of the deepening of the material as well as the current treatment practice. Although there are some students who look less active in the learning in the classroom, but the lecturer eyes of college trying to provide approach both in apperception, appreciation and motivates him to improve his spirits in process activities of learning care agency.

The use of media and learning resources is part of the components that influence learning. Materials teaching need to be adapted to the conditions of the students and strategies of learning that is used lecturer. Utilization and empowerment of modules to support learning is an advancement, not only to improve the effectiveness and quality of learning, but what is more important is to improve the mastery of the material both faculty and students.

To increase the activity of the participant students in the class in the process of learning, things that can be addressed by applying the model of learning, the success of a participant students in the process of learning is not only determined by the force instructor that good or curriculum that is steady, but is also determined by the method of learning the use of teachers. Models or methods of teaching that require activeness of students in accordance with the progress of students. Activeness learning students can be seen from the activities of learning students, among others: visual activities, oral activities, listening activities, writing activities, drawing activities, the motor activities, mental activities, and emotional activities [2]. 
To provide the material teaching in accordance with the development of the times, it can be assisted by the provision of a module teaching, a module teaching would be meaningless, if the student can with easy to use. The teaching modules that are currently in accordance with technological developments are electronic based. Teaching module electronics that when it popular is the Modular Object-Oriented Dynamic Learning Environment (Moodle), i.e. the module electronics are based on the web. Moodle is a name for a Program is an application that can transform a medium of learning into the form of a web [3].

In connection with this the author would like to develop an e- module that is by applying one of the models of learning in e-modules, namely discovery learning. Research that will writer to develop these, entitled "Development of E-Module Learning Care Agency -Based Discovery Learning on Student Program Study of Educational Makeup Universitas Negeri Medan".

Learning that effectively marked by the ongoing process of learning from the self-student. A person is said to have experienced a process of learning if in itself occurred change behavior of do not know be out, and not to be able to and so on. In the learning outcomes of learning can be seen directly, by because it was so that the ability of the students can be controlled and evolve as much as possible in the process of learning in the classroom then the program of learning that should be designed first advance by the teachers / lecturers with attention to various principles of learning that has been tested superiority wrong which is the source material of learning for participants learners.

Body means a science to learn how to take care body parts, so that the parts are not experiencing the changes were fatal or damaging the appearance. In order to implement the knowledge that the results are good then it must follow the instructions and perform the exercise, discipline themselves, and so on.

\section{E- Learning Module}

Electronic module or E-Module is an ICT-based module that has an interactive nature, makes it easy to navigate, allows displaying or loading images, audio, video and animation and it is equipped with tests or formative quizzes that allow feedback behind automatically with immediately [4].

Module electronics is a version of the electronics of a module that is already printed that can be read on the computer and is designed with the software that is needed [5]. E-module is a tool or a means of learning which contains the materials, methods, limits and how to evaluate which is designed as a systematic and attractive to achieve competence are expected in accordance with the level of complexity in electronics.

Some opinions regarding the understanding E-module can be concluded that the essentially e-module is a media electronic that can be accessed by students to have the benefits and characteristics are different. If the terms of the benefits of media electronics alone can make the process of learning more interesting, interactive, can be done when and where any and can improve the quality of learning.

\section{Sea Digital Learning (SIGIL)}

Sea digital learning is one of the learning virtual learning. Where learning that can be used for learning that do not require face-to-face, or can occur process of learning is not direct. Sea digital learning emphasizes the technology of using the internet to send learning materials to improve knowledge and skills. 


\section{Discovery Learning}

In the book Encyclopedia of the sciences of learning is learning Discovery learning is learning the invention is to learn from the study of contemporary in psychology cognitive to encourage the development of a method that is more specific, which defined its characteristics is that the participant students must produce units and structures of knowledge abstract like concept and groove by reasoning inductively their own about the case that is not abstract in a matter of learning [6].

The method of discovery (discovery learning) is a teaching method that regulates teaching in such a way that the child obtains knowledge that he did not know before, not through notification but partially or found himself [7]. By thus, in learning by discovery, students can gain knowledge from experience resolve the problem instead of through the transmission of a teacher.

Some opinions regarding the understanding of learning discovery learning it can be concluded that Discovery learning is a model of solving a problem that will beneficial for the children of students in the face of life in later days. The application of the model of discovery learning is intended that the student is able to understand the material change in the form of objects with as best as possible and learning more feels meaningful, so that the result of learning students also will increase. Because the discovery model of learning is in the process using the activities and experiences directly so that will be more attractive the attention of children of students and allow the formation of concepts abstract that has meaning, and its activity was more realistic.

\section{Research Method}

This research was conducted to produce an electronic module for learning body care. This research was conducted at Medan State University, Faculty of Engineering, Department of Family Welfare Education, makeup Study Program.

Subjects in the study this is a matter of learning the eyes of college nursing agency. While the object of the research it is the students Program Study of Educational Makeup who were studying the matter of learning the eyes of college nursing agency.

To find out the result of learning of students with the application of e- module learning care agency based discovery learning, the researchers did the collection of data research by using the instrument of research that tests and pieces of observation. Research was carried out in the form of observation of the entire activities of the process of learning to teach and aims to determine the changes that occur when do the action. Before sheet observation is used as an instrument of research, especially first sheet of observation is in validated by a team of expert validation.

To test the research instrument test, use a validity test, reliability tests, test the level of difficulty test, and different power test. Analysis of the data in the study is using stage test for normality, test of homogeneity, and t test. 


\section{Results and Discussion}

Results of the study showed; (1) the learning material expert test is in very good qualification $(93.75 \%),(2)$ the learning design expert test is in good qualification $(80.08 \%)$, (3) the learning video media expert test is in a very good qualification $(89,99 \%)$.

The result of the filing of hypotheses prove that: (1) the media e- modules of learning worthy of use in learning care agency on the program of study education that a dressing university land terrain, (2) there is a difference that is significant between the results of learning of students who be taught to use the e- module learning care agency with the result of learning of students who be taught to use the media to learn the book text. This is indicated by the results of data processing $\mathrm{t}$ arithmetic $=3.285$ at a significance level $\alpha=0.05$ with $\mathrm{dk} 40$ obtained $\mathrm{t}$ table $=1.67$, so $t$ arithmetic $>\mathrm{t}$ table, the effectiveness of using e- module body care learning $=$ $80.46 \%$. Results from study groups of students who be taught without the use of e-module learning care agency by $71.72 \%$. From the data have proved that the use of e- module learning care agencies more effective in improving the competence and knowledge of students on study treatment weight of at without using the medium of e- modules of learning care.

\section{Conclusion}

Based on the formula, objectives, results and discussion of research development of the emodule learning care agency that stated earlier, it can be summed up as follows:

1. After passing through several phases of test try, either test try of expert material, test try expert design learning, and test try from expert video and design graphics and test try to students, the product e- module learning dressing characters have the result already decent into the product end of the can be disseminated and implemented to the user. It is clarified with the acquisition of the average ratings almost all stages, i.e. in a test try expert materials on the table a scale of five, value that included the category "very good", the test try expert design learning in the tables scale of five, the value of the included category of "Good", In the trials of the experts in the five scale table, the value is included in the category of "very good", in the one-on-one trial in the five scale table, the value is included in the "very good" category, in the small group trials in the five scale table, the value is included in the category of "very good", in the field trials in the five scale table, the value is included in the "very good" category.

2. To see the effectiveness of the product, an analysis of student learning outcomes was carried out. Based on the analysis of student participants test try to group a large result of use of emodule learning care agency on the test results of learning of students showed that the result of learning of students who be taught to use the e-module learning.

\section{Implication}

The implications in question are as follows:

1. By using the e-module learning-based discovery learning will facilitate the students in the process of learning care agency, where media e-module learning care agency is equipped with theories, video implementation, and is equipped with test selection multiple that 
simplify, improve power remembered and power student reasoning in the learning process so that learning does not become normal anymore.

2. E-module learning care agency is very giving donations positive and practical, especially in the implementation of the process of learning for faculty where media learning this provides ease in organizing learning so that an impact on the effectiveness of the process of learning and can improve the outcomes of learning of students. With such media can be used as a material consideration for lecturers in the delivery of the material of lectures and in the field of science more with consideration where students have an interest in the process of learning will improve the results of their study.

Based on the conclusions above, it is suggested as follows:

1. During this process of learning to teach are implemented on the eyes lecture practice generally still use materials instructional media print, so it often happen refraction of learning. It is caused not achieve the ability to capture and apply knowledge that is acquired.

2. Media e-modules of learning in the eyes of college nursing agencies require their facilities room practices are adequate, so that at the time of the lecture took place not to be corrugated can do activities to learn together which will be more efficient in using the time to learn and have the time that is sufficiently long.

3. E-modules media of learning is just as a tool to assist in the delivery of learning, then the lecturers are still greatly needed as facilitators and students remain engaged actively in the process of learning the eyes of university.

\section{References}

[1] Mursid, R. Technology of Information and Communication (ICT) in Education -Based Higher Order Thinking Skills (HOTS). North Sumatra: CV. Echo Ihsani (2017).

[2] Sardirman. Interaction and Teaching and Learning Motivation. Jakarta: PT Raja Grafindo Persada (2007).

[3] Putra, KWB, Wirawan, IM A \& Pradnyana, GA. Development of E-Module -Based Model of Learning Discovery Learning On the Subject "Systems Computer" For Students Class X Multimedia Smk Negeri 3 Singaraja. Journal of Technology and Vocational Education. Vol. 14, No.1 (2017).

[4] Suarsana, IM and Mahayukti, GA. Development of E-Module Oriented Solving Problems to Improve Skills Thinking Critical Student. Indonesian Education Journal. Vol. 2 (2):266 (2013).

[5] Priyanthi, KA. Development of E-Modules Aided by Simulation Oriented Problem Solving in Data Communication Subjects, Case Study : Students of Class XI TKJ SMK N 3 Singaraja. KARMAPATI Journal. Volume 6, (2017).

[6] Seel, NM. Encyclopedia of Science of learning. New York: Springer (2012).

[7] Sudjana. Statistics Method. (6th edition), Bandung: Tarsito (2005).

[8] Solihatin, Etin and Raharjo. Cooperative Learning: Analysis of Social Studies Learning. Jakarta: PT. Earth Literacy (2008).

[9] Sudijono, Anas. Introduction to Educational Evaluation. Jakarta: PT. Raja Grafindo Persada (2011).

[10] Suprijono, Agus. Cooperative Learning: Theory and Application of PAIKEM. Yogyakarta: Student Library (2010). 
[11] Suprijono, Agus. Cooperative Learning. Yogyakarta: Student Library (2011).

[12] MKDP Curriculum and Learning Development Team. Curriculum and Learning. Jakarta: PT. Rajagrafindo Persada (2011).

[13] Tresna, Pipin. Basic Makeup: Makeup Face Day-Today. Bandung: Indonesian Education University (2010).

[14] Trianto. Integrated Learning Model. Jakarta: Publisher Literature Achievement (2007).

[15] Wiriaatmadja, Rochiati. Classroom Action Research Method. Bandung: PT. Teen Rosdakarya (2008). 